\title{
On the Literature of Roland Barthes
}

\author{
QIN Yan \\ China University of Mine and Technology of Xuzhou, Xuzhou, China
}

\begin{abstract}
For Roland Barthes, the literature is the only thing that we should save, because all science activities are expressed by the literature. The literature is a field of the hope and the meaning is instable. The literature affects the writer's social and the ideology, the attribute manners, and the consummation and the critics, and it is a creature. Roland Barthes explains from three parts: (1) the relation between the literature and the language; (2) the relation of the literature and the reality; and (3) the zero literature. Roland Barthes explains the structuralism and does not hurt the reality of the literature, because he thinks the literature exists in the forms and the systems and not in the content or function. Roland Barthes' point on the literature is a new manner and the angle and it is different from Sartres. The zero literature is a fervent imagination of the aesthetics of the language and the exception of the ideal, and it symbolize the aspiration for the freedom and the ideal world, so he affirms that the literature should be the Utopianism.
\end{abstract}

Keywords: the literature, the reality, the impossible

\section{Introduction}

If we should eliminate several disciplines from our education, there is one discipline that is exceptional, it is the Literature. The literature should be the only one to be saved, because all the science is expressed in the literature building. (Barthes, 1978, p. 18)

This is the Roland Barthes's words in his Lesson. He is skeptical about the language, but the literature is the frontier which gives us the hopes. For him, the literature has not a confirmed meaning. If we say that the writing is a significant, the literature is the process of the significance. Roland Barthes attribute the literature to the linguistics and try to make the freedom of the organization of the language and the freedom of the expression by breaking with the ideology and the idea of the classes. He objects to Sartres who associate the writing with the society and the history, and especially he objects to Sartres when he discusses the relation between the language and the literature because Sartres thinks the literature of the modernism from Flaubert is the lamentable and the amoral aberration and the "cancer" of the words. Roland Barthes proposes aesthetics of the "nonintervention". Now we begin to explain his points about the literature from three parts.

\section{The Literature and the Language}

In the classical literature, the language is a tool. It is determined by the meaning of the society and the form of the society, it has a single meaning. In the classical writing, the idea is the first and then is the language. This

QIN Yan, lecturer, master degree candidate, the China University of Mine and Technology of Xuzhou, Xuzhou, China. 
kind of writing often uses the past time to express clearly the world and the ideal world is sanctification. "Every thing is a state and the past time is just the sign of the function” (Barthes, 1991, p. 45). In the classical writing, the language, as a practical tool, is the decoration of the reality of the world and the expression for the love and the poems. The classical language mechanism is a connection, that is the expression and the choice of the words should be in favor of the expression of the relation. The classical language does not direct the meaning of the word itself and it is not the sign of the object itself. From the $19^{\text {th }}$ century, the literature and the language become more and more close, the linguistics build a " poetics”, describe the effect of the objects themselves but not connect with the object of reference. Roland Barthes begins a real revolution that makes the literature center on the language itself. "The language is a kind of literature, it is its own world, it dose not 'think', 'describe', 'narrate', 'feel'” (Barthes, 1984, p. 13). The two functions of the language is contradictory: One is the function of the communication and the other is the function of the poetics. The function of the communication cannot explain completely the repeatability of the literature. For Roland Barthes, the traditional criticism praise itself as fair and objective, in reality, it is behind the appearance of the mythology and the capitalism that we should build a timeless and super history literature, which is eternal. So the works should be written by his own model. In the modern writing, the language eliminate a kind of intention and the language burst forth. We do not attach importance to the relationship between the words and the society but the words themselves. "From Flaubert to our age, all the literature becomes a problem of the language” (Barthes, 1992, p. 18). Because in the world of Roland Barthes, it is full of the interval and the light of the words which have the instable factors and have the rich meanings. In this world, the words have not the anticipated intention and the eternal purpose. This kind of open, unceasing and ambiguous words is the passage to the supernature and this kind of words is the necessity to the freedom of the language and then the freedom of the human beings (Xiang, 2003, p. 37).

The meaning function of the language liberates the language from the ideology.

The literature is to battle with the first language (we often name it like this)...... We often say that the literature often express those we cannot express. But I think it is opposite, the literature does not express those we can express. (Barthes, 1964, pp. 14-15)

In order to break the poor and ordinary language and avoid the death of the literature, we form a "indirect language”, but in reality it is just the "exact language”. For example, when we express the sympathy of a friend who has just lost parents, we should use a manner of doing in a "indirect way". If we use the word "condole", it is "exact”, but it seems cold and impolite. Like what Shklovsky (Shklovsky ,1989, pp. 6-7) said, the literature language is born "strange", it will break the rules of the daily language and bring a sensation of freshness and make the literature dynamic. For example, in The Little Granddaughter of M. Lin of Philippe Claudel, the writer does not write directly the sad feeling of M. Lin who has left his hometown because of the war, but describe that he cannot taste the seawater to express his sad feelings. In the novels of Queneau, he also uses a lot of new words.

Roland Barthes finds that the literature has also the double organization like the mythology. The first system of the meaning is formed by a form and the content, and these two things form the lay of expression of the second system, but its signs signified are different from those of the language. Roland Barthes praise highly the pluralism of the meanings, and he thinks the meaning of the literature is to battle with the signified signs limited by the significant. He tries to found an open literature that we can "write" and the readers can intervene. His points on the text is to pursuit a happiness. 


\section{The Literature and the Reality}

From Aristote, the literature is "imitation", that is the literature is the copy of the reality, the meaning of the novel exists in its relation with the world, the literature is the complete expression of the world. But in 20th century, it was impossible to understand the whole world, the closed idea of the world was impossible; we could know the world partly, and the pluralism of the science question the "imitation".If we say that the literature is conscious of the untruth, then the reality of the literature does not exist in the expression of the actual world but to tell the part that is not real in the actual language. For Roland Barthes, when the literature wants to describe the real world, it will be more far from the real world and it cannot surmount the language and reflect the real world. The text should become open and ambiguous, even we should cancel the meanings that we can attain the freedom and reality.

About how to write, the writer creates a game of the significant whose signified is open, and cancels the limit of the signified is the eternal theme of Roland Barthes.Roland Barthes proposes in his $S / Z$, the main standard of the modern writers is the pluralism of the meaning of the text. Of course, he said that this pluralism of meaning is only the incomplete and proper pluralism. He said when we narrate an history, we should not limit the meaning in exact and final way, like what some kind of social words tell us to do. He tries his best to create a "shake meaning” to liberate the oppression of the social meaning. This kind of dialectical relation between meaning and non-meaning, nomination and non-nomination, life and death found the mythology of the literature. He thought when we explain a text, we should not give it exact meaning but to see it can product what kind of pluralism of the explanation of the meaning. The ideal text is like a web, we can enter it from any entrance.

In order to avoid the fix of the meaning, he breaks the Sarrasine of Balzac. The title "Sarrasine" can be explained in a several meanings: (1) the ordinary nouns or the proper nouns; (2) a person or a object; and (3) a man or a woman (because in French, the ending "e" is a sign of a women).

He distinguishes two kinds of writings: the readable and the writable writings. The readable text can be read but cannot be written again. The writable text demands active reading, it makes the readers the partners of writing the texts. The readable text will not point out its secret codes of the rhetoric. Like several classical texts, affected by the determinism, those texts abide by the principal of the similitude and the logicality. This kind of reading is passive and suffers a lot of burden of the signified. He thinks the value of the text is to fight with the signified which limits the significant. The real text is not the exact and clean explanation of the world, but says nothing. The literature can call in question the world, the belief, and the ideology. It can disperse the fraudulence of the ideology even it does not give the answer.

In the theater of Brecht, there is a meaning connected with the ideology of the Marxism, Brecht thought that the world is real and identifiable, if we want to describe the world, it will be possible when we think that it can be transformed.(Brecht.1992, p. 89) His meaning of the theater is not fixed and he refuses to give a complete answer and a dogmatism answer. He does not dispose his theater with the political intention but with a lot of disposition of the significant, such as the disposition of the searchlight, intervention of a song, or insert a sign or a reading of an actor to realize the meaning.

To improve the language is to break the reality, and we think the reality is describe by the persons and precede the text. And the surpass of the language is to fight with the complete meaning, power, science, and 
reason. He also distinguishes the writer and the man who writes the words. The man who writes the words is satisfied to express clearly but the writer is against two conditions of the words: One is doctrine, the other is proof. The writing is intransitive. He does not express something, he just write and the language become the object and not a tool.

\section{The Zero Degree of the Writing}

The conception of "the zero degree" comes from the linguist of the Denmark Vigo Brondal, it means the neutral and has not sign. In the Linguistics, the indicative and subjunctive (the sign is to express the doubt and intention) is the neutral forms. Roland Barthes wants to found a neutral, white, and apathetic writing. In the "strange man" of Camus, the first phrase of the novel is: "The mother is dead". The phrase is very cold and neutral. The action of the figures is very mechanical, it open a road of the zero writing. For the description of the objects, the new novel refuse a degree of the depth and the inhesion. They only record and the objects often become the theme of the novel and they, not like in the traditional works, are no longer the auxiliary of the theme. For example, the description in the novels of Flaubert is psychogenic, and the description of objects in the Proust is memorial, and in Peeping Tom of Alain Robe Grillet, the writer does not describe the direct murder of the little girl but to describe the repeated presence of the girl, the line, the wood pile, and the bonbon, and makes the readers to guess the truth. For example, the surrealism uses the automatic writing to cancel the subjectivity.

When Sartre tells about the literature, he calls to abandon the passivity of the writer. We should intervene and write for the others and not write for express yourselves. The language of the writer who intervenes is action purpose is to disclose and change. But Barthes advocate a writing silent, a white and zero writing, the writer quit the text and become an absent writing. This kind of writing expresses the ideal of the aesthetics of Roland Barthes. It cancels the political value and the utilitarian. Barthes has expressed the "language beyond the touch of the intransitive world".

In the 20th century, there was another viewpoint of Maurice Blanchot. He compares the literature with the death; he does not try to search the meaning of the literature but to enlarge the silence of the literature, cancel all the meaning of the literature; he refuse to explain the text and only give the literature one explanation.

The zero literature is from the Roland Barthes's detest of the utilitarian and the ideology. But as a product of the ideology, the literature is sure to have the characteristic of the ideology, so the real white writing does not exist. Roland Barthes has realized it and says that it is only the characteristic of the modern French literature.

In reality, the literature cannot be separated from the society. The literature of the 20th century reveals the rupture between the literature and the world. "The literature cannot control the reality of the history, the works passé from a system of representation to the symbolic game system” (Barthes, 1981, p. 193). The literature is not only limited by the ideology but also arm to battle with the ideology. Balzac, in the 19th century, lashed the capitalist who seeks nothing but the profits and they are cool and praise highly the money. Victor Hugo, as a humanist, sympathize the poor people and the proletariat.

In reality, the zero writing of Roland Barthes is another way to intervene. He uses an ideal form of the literature to express his idea of the aesthetic of the literature and his ideality of the society. Perhaps just like the Mosul of Camus, the writer exists in the blank of the novel and the mechanism of the action of the figure possesses the pluralism of the meaning. "The figures present a rich meaning thought the appearance is so simple, 
like a ice mountain, those appear so small but cover a lot” (Guo, 2007, p. 239).

And a lot of viewpoints of Roland Barthes seem to have a characteristic of a game in order to pursuit a final happiness. So after these questions, he does not give the answers. From the structuralism to deconstruction, someone thinks Roland Barthes often changes. But in reality he is a writer rather than a theorist. His works are from his own sentiment and destroy the tradition to express his ideality and in the battle to break the ideology, he proposes a "Utopia" of the language. He wants to break the oppression of the world and realize the absolute freedom of the people. Roland Barthes's theory gives us a particular way to see and affect profoundly the 20th century and later.

\section{Conclusion}

The traditional literature looks the literature as the system of the signifiants, but Roland Barthes looks the literature as the system of the signified. He attract the readers to the language of the literature and appreciate the plurality of the text. He is against the reality of the classical writers. The developpement of the 20th century need us to reevaluate the reality of the world. He breaks the text into pieces and avoid the immobilization of the meaning. This is the demand of the epoch. His zero degree wrting is the other way to intervene the epoch, he uses a perfect way to explain his points on the literature and he looks foward to the freedom of the humanity. His contribution in literary criticism and the art is inestimable in the world.

\section{References}

Barthes, R. (1964). Critical essay. Paris: Seuil.

Barthes, R. (1978).The lesson. Paris: Seuil.

Barthes, R. (1981).The seed of the voice. Paris: Seuil.

Barthes, R. (1984). The croon of the language. Paris: Seuil.

Barthes, R. (1991). Writing degree zero. In S. Sontag (Ed.), A Barthes reader. New York: Hill and Wang.

Barthes, R. (1992). The zero degree of the writing. Taibei of China: The limited liability Company of the culture of the Shibao.

Brecht. (1992). Brecht comments the drama (Ding Yang zhong etc., Trans.). Beijing: The Publishing House of the Chinese Drama.

Guo, R. A. (2007). From Montaigne to Camus-The reconstruction of the space of the lecture of the French literature. Shanghai: SDX.

Shklovsky. (1989). The Art as the technique. Shanghai: SDX.

Xiang, X. M. (2003). The zero degree writing and the freedom of the humanity-The study of the spirit of the esthetics of Roland Barthes. Shanghai: The Publishing Company of the Fudan University. 